\title{
Wanda Baranowska
}

Uniwersytet Łódzki

E-MAIL: wanda.baranowska@now.uni.lodz.pl oRCID: oooo-ooo1-7793-2533

\section{Teoria umysłu, oczekiwania społeczne a sytuacja osób z zaburzeniami w spektrum autyzmu, w tym z Zespołem Aspergera}

\begin{abstract}
STRESZCZENIE:
$\mathrm{W}$ artykule podjęto próbę analizy stanu badań nad teorią umysłu oraz jej deficytem u osób z zaburzeniami ze spektrum autyzmu (ASD), szczególnie z Zespołem Aspergera (ZA). Poszukuje się w nim również związków teorii umysłu z oczekiwaniami, które wyznaczają reguły współzależności społecznej. W świetle analizowanych badań można stwierdzić, że teoria umysłu wiąże się, przez powszechne oczekiwanie empatii, z potrzebą i regułą akceptacji i szacunku. Biologicznie uwarunkowany deficyt teorii umysłu u osób z ASD prowokuje wysokie ryzyko ich odrzucenia jako niespełniających społecznych oczekiwań.

SŁOWA KLUCzowe: teoria umysłu, zaburzenia w spektrum autyzmu, Zespół Aspergera, oczekiwania społeczne
\end{abstract}

\section{Wprowadzenie}

Zespół Aspergera (ZA) jest przewlekłym neurorozwojowym zaburzeniem interakcji społecznych i komunikacji. Charakterystycznym rysem tego zaburzenia są silnie zogniskowane zainteresowania i ograniczenia w zachowaniach społecznych. Choć wiąże się z pełnosprawnością intelektualną oraz prawidłowym rozwojem języka, to jednak jest uznawany za istotną niepełnosprawność społeczną utrzymującą się przez całe życie (Woodbury-Smith i Volkmar, 2009). W świetle aktualnie obowiązującej w Polsce klasyfikacji nozologicznej ICD-10 (WHO, 2008) jest wyodrębnioną jednostką w grupie całościowych zaburzeń rozwoju. W przyjętej w 2013 roku przez Amerykańskie Towarzystwo Psychiatryczne klasyfikacji DSM-V, jak i planowanej do wdrożenia przez Światową Organizację Zdrowia klasyfikacji ICD-11 może być jednym z trzech poziomów nasilenia objawów oraz stopnia ich wpływu na codzienne funkcjonowanie, rozpatrywanym w spektrum zaburzeń autystycznych. 
Stwierdzenie zaburzenia interakcji społecznych w diagnozie ASD/ZA następuje na skutek obserwowanego obniżenia poziomu empatii społecznoemocjonalnej, wślad za tymi nieadekwatnymi reakcjami emocjonalnymi, trudnościami w inicjowaniu kontaktów z rówieśnikami i w nawiązywaniu przyjacielskich relacji (Szamburska-Lewandowska i in., 2020), co odnosi się do deficytów w teorii umysłu (Baron-Cohen, 1995; Frith, 2001), w centralnej koherencji, która jest zdolnością do integrowania informacji z różnych źródeł i hierarchizowania ich (Frith i Happé, 1994) oraz w zakresie funkcji wykonawczych. W ślad za pierwotnym opisem zaburzenia, dokonanym przez Hansa Aspergera (1944), uznaje się, że osoby z ZA są egocentrycznie ukierunkowane na postrzeganie świata społecznego i jego reguł, co przekłada się na pejoratywną ocenę ich społecznego funkcjonowania. Konsekwencją tak sformułowanej charakterystyki osób z ZA jest oferowanie im interwencji terapeutycznych, w przebiegu których podwyższą poziom deficytowych kompetencji, ze szczególnym naciskiem na umiejętności społeczne, w tym komunikacyjne, dopasowując je do potrzeb „pełnosprawnej większości” społeczeństwa. Ta większość w zasadzie nie poddaje analizie i ocenie reguł społecznej komunikacji, uznając je za akceptowane i przez siebie oczekiwane, zakładając jednocześnie, że „kłopot” leży po stronie osób z ZA, wszak posiadają deficyty w teorii umysłu, a „rację” mają wszyscy pozostali, u których rozwój teorii umysłu i kompetencji komunikacyjnych jest „typowy”. Konsekwencją takiej opinii jest formalne i potoczne uznanie "niepełnosprawności” osób z ZA, które osiągając dorosłość ową "metkę” często odrzucają, przyznając jednocześnie, że odczuwają trudność w rozumieniu stanów mentalnych innych ludzi oraz motywów, jakimi osoby neurotypowe kierują się tworząc komunikaty w sytuacjach społecznych. Taki sprzeciw generuje chęć rozpoznania podstaw konfliktu opinii, jaki tworzy się pomiędzy osobami z ZA a pozostałą częścią społeczeństwa.

Celem niniejszego artykułu jest syntetyczne opisanie na podstawie aktualnego stanu badań, istoty teorii umysłu oraz mechanizmu formułowania, zakotwiczonych w niej oczekiwań społecznych, do czego odnosi się pierwsza część tekstu. Druga część jest wynikiem analizy literatury, przeprowadzonej w celu ukazania sytuacji osób ze spektrum zaburzeń autystycznych, w tym z ZA, wynikającej z biologicznie uwarunkowanych deficytów w teorii umysłu, jaka wiąże się z oczekiwaniami społecznymi, formułowanymi przez społeczeństwo rozwijające się typowo. Treść drugiej części tekstu wzbogacają surowe wypowiedzi dorosłych, uktórych formalnie rozpoznano ZA pochodzące $\mathrm{z}$ wszczętych, ale nie zakończonych badań własnych w ramach projektu „Percepcja świata społecznego przez dzieci i dorosłych z Zespołem 
Aspergera”, w którym zaplanowano analizę wszelkich wytworów badanych, ujawniających ich „wypowiedzi” na temat świata społecznego.

\section{Teoria umysłu}

Wśród badaczy nie ma zgodności, czym jest „teoria umysłu” (z języka angielskiego Theory of Mind, nazywana w literaturze skrótem ToM). Jedni zakładają, że jest selektywną zdolnością poznawczą, wyspecjalizowaną w przetwarzaniu informacji o stanach mentalnych (Leslie i Thaiss, 1992; Frith i Frith, 2003; Brune i Brune-Cohrs, 2006). Inni uważają, że raczej uczestniczy w tworzeniu metareprezentacji różnego typu i wchodzi w związki z innymi procesami poznawczymi (Astington i Jenkins, 1999; Carlson i in., 2004). Na potrzeby niniejszego artykułu, związanego z sytuacją osób z Zespołem Aspergera, integruję poglądy badaczy, traktując teorię umysłu (zwaną zamiennie „mentalizacją”) jako specyficzną zdolność poznawczą, niezależną od pamięci i myślenia abstrakcyjnego, automatycznie aktywowaną na skutek bodźców o charakterze intencjonalnym, biologicznie uwarunkowaną, typową tylko dla ludzi zdolnością, umożliwiającą społeczne poznanie (Leslie, 1987). Ogólnie jest zdolnością do wyjaśniania i przewidywania własnego zachowania i innych przez przypisywanie im niezależnych stanów mentalnych, takich jak przekonania, pragnienia, emocje lub intencje. Jest także zdolnością do oszukiwania, współpracy i empatii oraz czytania języka ciała innych osób (Brune i Brune-Cohrs, 2006; Gallagher i Frith, 2003). Całożyciowy rozwój tych zdolności pozwala ludziom m.in. na dzielenie $\mathrm{z}$ innymi pola uwagi, odróżnianie przedmiotów rzeczywistych (obiektów) od mentalnych (myśli), zauważanie i rozumienie nieliteralnej mowy, w tym metafor, ironii, czy też kłamstwa i żartu. Zgodnie z jednym z modeli ToM pozwala ona na dzielenie pola uwagi, śledzenie kierunku patrzenia innych osób, rozpoznawanie twarzy, identyfikowania emocji przez rozpoznawanie cech prozodycznych mowy (Stone i Gerrans, 2006). Inne badania pozwalają założyć związek ToM z identyfikowaniem emocji przez odczytywanie mimiki twarzy (Dawson i in., 2004).

W teorii umysłu zawiera się także umiejętność wychwytywania niezręczności w relacjach towarzyskich, zwanych faux pas (Brune i Brune-Cohrs, 2006), umożliwiając zachowanie wysokich standardów „kultury osobistej”.

Podsumowując można stwierdzić, że teoria umysłu niesie implikacje istotne dla wielu aspektów funkcjonowania dzieci i młodzieży, takich jak kompetencje społeczne, akceptacja rówieśników i wczesne sukcesy w szkole (Carlson i in., 2013), które spójnie tworzą społeczną pełnosprawność jednostki i grup społecznych. 
Model mentalizacji opracowany przez Alana Lesliego (1994) sugeruje, że mechanizm teorii umysłu zależy od przedstawienia wyobrażonych okoliczności „oddzielonych” od rzeczywistości.

Interpretując zachowanie danej osoby za pomocą przekonania, uznaje się, że przekonanie to może nie odpowiadać rzeczywistości, w której zachowania innych są zależne od ich personalnych celów, co więcej - wynikających $\mathrm{z}$ innego, niż posiadane przez interpretującego, spojrzenia na świat. Zwykle nie ma problemu z rozdzieleniem i porównaniem obu perspektyw. W komunikację werbalną wplata się swobodnie „...ja myślę, że on widzi to inaczej...”, „...jestem pewna, że ona postąpiłaby...”, „....sądzę, że obie myślimy/działamy tak samo..." i inne. Zdolność rozumienia zachowań innych odwołuje się także do pewnych oczekiwań, wynikających z ogólnej wiedzy o świecie, o konkretnej osobie oraz z obserwacji tego, co ta osoba robi. Szczególnie istotny jest rodzaj wiedzy o świecie, który określa się mianem skryptu (Schank, 1982; Schank i Fano, 1995). Skrypty rejestrują konkretne cele i działania, ulokowanie w określonym miejscu i ustawione w określonym czasie (Gallagher i Firth, 2003), np. cele związane ze „skryptem szkoła”, „skryptem pływalnia”, czy „skryptem lodziarnia”. Przewidując zachowanie innych, np. w szkole zakładamy, że uczniowie przyszli się uczyć, bawić, spotkać z rówieśnikami, będą mówić, czytać i pisać. Przyniosą ze sobą książki, zeszyty, przybory pisarskie, spędzą w szkole określony czas. Żaden z uczniów do szkoły nie przyniesie kostiumu kąpielowego, nie będzie oczekiwał od nauczyciela „menu” i nie będzie jadł lodów. I odwrotnie, zdziwimy się i prawdopodobnie negatywnie ocenimy, gdy uczeń na lekcji będzie jadł lody, na pływalnię przyniesie plecak z książkami zamiast kostiumu, do lodziarni wejdzie osoba z mokrymi włosami i zamiast prosić o menu, czy kupić lody, na stojącym tam krześle rozłoży kapiący ręcznik. Przy poprawnie działającej teorii umysłu wiadomo też, że w szkole nauczyciel wyciągający rękę do ucznia nie oczekuje od niego kostiumu kąpielowego, a sprzedawca w lodziarni nie poda klientowi podręcznika do matematyki. Na takich właśnie skryptach osadzone są reguły społecznej współzależności, oczekując od wszystkich respektowania zawartych w nich „oczekiwań”. Skrypty stają się kontekstem procesu wychowania, co np. sugerują badania Pears i Moses (2003), potwierdzając związki teorii umysłu z wychowawczym działaniem matek o określonych cechach demograficznych.

Próbując określić związki teorii umysłu z regułami (czy też wartościami) współżycia społecznego można wskazać po pierwsze, oczekiwanie od ludzi empatii i potwierdzającej ją komunikacji, w tym współodczuwania nastroju, dzielenia radości i smutku, oferowania pomocy, gdy „wyczuwa się” taką 
potrzebę innych. Oczekuje się, by osoba widząca niepewny wyraz twarzy swojego bliskiego czy kolegi zapytała „jak mogę pomóc?”, by pytano „czy napijesz się herbaty?” w mroźny dzień, a widząc zaniedbanego, „zgorzkniałego" człowieka, by przefiltrowano myśli i mówiono „dobrze wyglądasz”. Ogólnie tę regułę współżycia społecznego nazywa się szacunkiem i akceptacją i trudno nie zgodzić się z jej dobroczynnym działaniem. Po drugie, przywiązuje się dużą wagę do dzielenia $\mathrm{z}$ innymi pola uwagi oraz inicjowania wspólnego pola, co jest powszechnie traktowane jako wyraz integrowania się ludzi przez wspólny punkt odniesienia, np. na chwilowych zainteresowaniach, na konkretnym obiekcie-przedmiocie lub osobie. Nawiązywanie kontaktu wzrokowego, podążanie za wzrokiem czy też wskazującą coś ręką rozmówcy generuje dobre samopoczucie. Odnosi się wówczas wrażenie, że rozmówcy rozumieją siebie nawzajem, tworzą wspólnotę, mogą sobie nawzajem ufać. Choć w skali mikro, to takie zdarzenia zaspokajają potrzebę bezpieczeństwa, akceptacji i uznania i odnoszą się do tak samo zwanych reguł. Po trzecie, wytworzono w ramach reguł społecznych tzw. kulturę wypowiedzi, w której nie występują frazy godzące w dobre samopoczucie jednostek. Mówiąc potocznie, oczekuje się miłych słów, nawet wtedy, gdy nie odzwierciedlają prawdy. W ramach owej kultury, poza treścią wypowiedzi, stosując określoną prozodię oczekujemy zrozumienia ludzkich intencji i nastroju. Te trzy aspekty stanowią ważne komponenty czegoś, co nazywamy pożądanymi umiejętnościami społecznymi i z czego tworzymy cel wychowania.

Dokonując różnorodnych prób zdefiniowania umiejętności społecznych zakłada się, że są one społecznie akceptowalne (zatem zgodnymi z oczekiwaniami, opartymi na dobrze rozwiniętej teorii umysłu - przyp. autorki), wyuczonymi zachowaniami, które umożliwiają jednostkom kompetentne funkcjonowanie w różnych zadaniach społecznych (Moody i Laugeson, 2020). Opisując proces wychowania stwierdza się, że „polega na celowym oddziaływaniu ludzi dorosłych (wychowawców, nauczycieli) na dzieci i młodzież (wychowanków), w celu ukształtowania w nich określonych pojęć, postaw, dążeń i wartości w warunkach konkretnej rzeczywistości społeczno-cywilizacyjnej”, przy czym „wartości są pochodną potrzeb, realizacją potrzeb - ich hierarchia odzwierciedla hierarchię potrzeb człowieka" (Świtała, 2019).

Można powiedzieć, że oczekuje się i dąży w wychowaniu do „idealnego” świata i zaspokajającej ludzkie potrzeby interakcji społecznej, w której liczne skrypty wywołują jednorodnie pożądane emocje i działania. Zdarza się jednak, że uwarunkowana biologicznie grupa społeczna takim oczekiwaniom nie jest w stanie sprostać. 


\section{Deficyt teorii umysłu u osób z zaburzeniami ze spektrum autyzmu, w tym z ZA}

- Czy jest Pan w stanie przyjąć, że inni mają na ten temat odmienne zdanie?

- Tak, jestem w stanie. Nie rozumiem tylko dlaczego się mylą (Fragment wywiadu autorki z Mariuszem z ZA, lat 37).

Teoria umysłu jest od wielu lat wykorzystywana do formułowania opinii i prognoz dotyczących upośledzenia socjalizacji u osób z autyzmem (Frith i Happé, 1994). Zgodnie z opinią Uty Frith (2004) deficyt teorii umysłu, polegający na niezdolności wyobrażania sobie stanu umysłu innej osoby, czy też dokładnie tego, co myśli inna osoba, tłumaczy obecne w zaburzeniach ze spektrum autyzmu (ASD), w tym w ZA upośledzenie porozumiewania się, wyobraźni i kontaktów z ludźmi.

Relacje międzyludzkie zawsze stanowiły dla mnie problem, gdyż nie potrafiłam zrozumieć, a co dopiero wyobrazić, myśli innych. Zakładałam, że zanim z kimś się zaprzyjaźnię, potrzebuję sporządzić raport. (...) na wstępie dawałam sto procent zaufania petentowi, następnie wdrażałam zasadę maksimum czasuminimum oceny zachowania/poglądów, bywałam wtedy pełna wyrozumienia, szacunku i nigdy nie zwracałam się zdrobnieniami, wszystkie dane zapisując w głowie jak „założenia i dane do rozwiązania zadania matematycznego/logicznego" (Fragment wywiadu autorki z Olgą z ZA, lat 24).

Agnieszka Pluta (2012), dokonując zestawienia stanu badań nad teorią umysłu zwraca uwagę, że koncepcja modułowa teorii umysłu wyjaśnia deficyty poznawcze u osób w spektrum zaburzeń austystycznych, które wykazują, izolowaną od myślenia abstrakcyjnego i samokontroli, dysfunkcję w dokonywaniu atrybucji stanów mentalnych innych osób. Prowadzone aktualnie badania nadal ujawniają niskie wyniki w zakresie empatii poznawczej i afektywnej u nastolatków z objawami ASD (Kerr-Gaffney i in., 2020), niską reaktywność emocjonalną dorosłych oraz niższe niż grupa neurotypowa umiejętności społeczne (Pepper i in., 2019). Potwierdzają też pojęcie domniemanego deficytu teorii umysłu w zaburzeniach ze spektrum autyzmu, formułując jednocześnie pogląd, że doświadczenia mogą wpływać na przewidywanie zachowania (Jakobson i in., 2018).

Badania Sodian i Firth (1992), dotyczące zdolności do oszukiwania lub przeszkadzania przeciwnikowi w zdobyciu nagrody wykazały, że dzieci z zaburzeniami $\mathrm{w}$ spektrum autyzmu $\mathrm{w}$ zasadzie nie radzą sobie $\mathrm{z}$ kłamaniem, ale z łatwością uniemożliwiają konkurentowi zdobycie nagrody poprzez manipulację fizyczną (w eksperymencie chodziło o sabotaż, polegający na zamknięciu pudełka z nagrodą), co potwierdza, że dzieci autystyczne mają 
specyficzny deficyt $\mathrm{w}$ rozumieniu i manipulowaniu przekonaniami. Podobne wyniki uzyskali Begeer i in. (2003).

Można zatem uznać, że osoby z ZA nie są lub są zdecydowanie mniej empatyczne niż osoby neurotypowe, ale proces wychowania i generowanych w nich doświadczeń może wspierać je w rozwoju umiejętności przewidywania oczekiwań zawartych w skryptach. Oznacza to, że nie są zdolni do współodczuwania nastroju innych ludzi, mogą się cieszyć i smucić niezależnie od samopoczucia innych, a pomocy udzielą tylko wtedy, gdy inni o nią poproszą, ponieważ nie „wyczuwają" lub nie czytają z zasłyszanych słów potrzeby innych.

- Padam na twarz, napiłabym się herbaty.

- (Cisza).

- Słyszałeś? Napiłabym się herbaty.

- Słyszałem (siedzi nadal).

- Jezuuu, no zaparzysz dla mnie herbatę?

- Tak. Chcesz zieloną czy czarną? (Fragment z Dziennika zdarzeń, prowadzonego przez żonę Piotra z ZA lat 31).

Deficyty w rozwoju teorii umysłu sprawiają, że w przypadku osób z ZA nie powinno się oczekiwać spontanicznego współczucia i wyważonych (przefiltrowanych oczekiwaniami innych) wypowiedzi. Słaba centralna koherencja wyzwala wysoką zdolność do zauważania pojedynczych cech i jednocześnie znaczne problemy z postrzeganiem i rozumieniem całości sytuacji społecznej, sprawiając, że „coś” widzą i słyszą przez pryzmat szczegółów i o tym komunikują. Nie kierują się chęcią wyrażenia jakiejkolwiek oceny, która odnosi się do zaspokojenia potrzeby szacunku i akceptacji innych. Nie mają zamiaru sprawić komukolwiek przykrości i nie rozumieją o co chodzi, gdy takie działanie lub wolę im się zarzuca.

- Ona ma dużą głowę.

- Nie mów tak proszę, sprawiasz jej przykrość.

- Ale ona ma dużą głowę.

- A ty jaką masz głowę?

Kilkanaście sekund ciszy...

- Ona ma dużą głowę, ja mam okrągłą głowę (Fragment Dziennika zdarzeń, prowadzonego przez mamę Bartka z ZA, lat 8).

Osoby z ZA w formułowanych przez siebie i zasłyszanych komunikatach nie dostrzegają wieloznaczności. Jak pisze Dorota Karpińska (2011) nie wiedzą, co to „drugie dno” czy „druga strona medalu”. Sprawia to, że mają również istotne trudności w zrozumieniu podstępu czy oszustwa, stając się np. 
„ofiarami” szkolnych lub pracowniczych żartów, a w skrajnych sytuacjach w przypadku dziewcząt i kobiet także ofiarami różnego rodzaju nadużyć oraz wykorzystania seksualnego (Rynkiewicz i in., 2019).

Mając okazję doświadczania wieloznaczności uczą się rozumienia sytuacji społecznych, budując własne, subiektywne skrypty, co potwierdza poniższy cytat.

Tak sobie myślę, że nie potrafię wyłapać z rozmowy sarkazmu. Abstrakcja dla mnie. Mimo, że się uczę. Czasami mi się jednak udaje i wtedy cieszę się jak dziecko! Ale nie do tego zmierzam - mój tata wychował mnie i siostrę na dzieci, z którymi może porozmawiać na konkretnym poziomie (wiadomo - wysokim), więc potrafię np. wczuć i zrozumieć każdą z przenośni i metafor mojego taty (Fragment wywiadu autorki z Olgą z ZA, lat 24)

Nietypowy wzór zachowania w kontakcie wzrokowym jest jednym z najbardziej znaczących objawów ASD w okresie dziecięctwa i dorosłości (Winczura, 2014; Senju i Johnson, 2009). Choć należy pamiętać, że osoby z ZA nie są grupą homogeniczną, to wielu próbując sformułować wypowiedź mruży lub przymyka oczy lub zdaje się patrzeć „przez” swojego rozmówcę. W takim zachowaniu nie są zawarte żadne intencje, unikanie kontaktu wzrokowego jest modulowane przez pracę mózgu, co ujawniły liczne badania (Grice i in., 2005; Pelphrey i in., 2005; Senju i in., 2005) i co jest związane z mentalizacją lub teorią umysłu (Decety i Lamm, 2007; Saxe i Wexler, 2005).

W świetle opisanych wyżej aspektów można zauważyć, że deficyty umiejętności społecznych są wszechobecną i trwałą cechą zaburzeń ze spektrum autyzmu (ASD), wobec czego licznie poszukuje się efektywnych strategii interwencyjnych i terapeutycznych (Bellini i Peters, 2008; Koning i in., 2013; Ratcliffe i in., 2014). Sugeruje się użycie w nich historii społecznych, modelowania wideo, strategii rozwiązywania problemów społecznych, szkolenia z zakresu podstawowych reakcji, procedur skryptowych, interwencji komputerowych oraz wielu innych. Stosując rekomendowane strategie terapeuci i edukatorzy mają nadzieję „obronić” osoby z ZA przed porażkami w kontaktach społecznych, które w skrajnych przypadkach oznaczają odrzucenie, zapominając zbyt często, że nie są one jedynymi uczestnikami społecznych interakcji i tym samym zaniedbując przygotowanie neurotypowej większości do uczestnictwa w relacjach z osobą z ZA. Tę „nierówność troski” sygnalizuje poniższa wypowiedź osoby z ZA.

(...) miałam wówczas jednego kolegę, który był szurnięty i to w nim lubiłam, ale najbardziej - nie oceniał książki po okładce i był jedyną osobą, która mnie nie 
przekreśliła, ale znaliśmy się raptem półtora roku i wyjechał z kraju z rodzicem. A był jedyną osobą, która pożyczała mi zeszyty, (...) i która zapraszała mnie do siebie na granie na komputerze i ciasto. Po jego wyjeździe, moi rodzice musieli wraz ze mną chodzić po domach „koleżanek”, żeby pożyczyły mi zeszyty na słownie kwadrans do skserowania, bo mi zawsze odmawiały (Fragment wywiadu autorki z Olgą z ZA, lat 24).

Dalekosiężnym celem oddziaływań terapeutycznych staje się nabycie przez osoby z ZA umiejętności społecznych przydatnych w edukacji, zawodowym i codziennym życiu, w którym będą wykorzystane do radzenia sobie ze złożonymi interakcjami i dynamiką grupy (np. zawieranie znajomości, współpraca przy projektach szkolnych, nawiązywanie przyjaźni, umowy ze współlokatorami w akademiku czy negocjowanie warunków pracy i wynagrodzeń $\mathrm{w}$ dorosłym życiu). Interwencjom i strategiom terapeutycznym towarzyszy ogromny wysiłek osób z ZA, ich rodzin oraz terapeutów. To działanie respektuje fakt biologicznie uwarunkowanych deficytów w teorii umysłu osób z ASD, w tym z ZA, co do istoty jego zadaniem jest wyuczenie zachowania symulującego stan dobrze rozwiniętej mentalizacji, by odpowiedzieć na potrzeby i oczekiwania neurotypowej większości. I na tym w głównej mierze opiera się nie tylko proces terapii, treningów umiejętności społecznych, ale również proces wychowania dzieci i młodzieży z ZA oraz innymi zaburzeniami ze spektrum autyzmu.

\section{Podsumowanie}

Dobrze rozwinięta teoria umysłu pozwala ludziom być „ludzkimi” - lubić, kochać, wyczuwać emocje innych i przychodzić w sukurs ich potrzebom. Do takiego świata człowiek został zaprogramowany przez wyposażenie w umiejętność mentalizacji i do rozwoju takich kompetencji dąży się w procesie wychowania. Taki stan nazywamy „pełnosprawnością”.

W świetle przywołanych w niniejszym artykule opracowań i wyników badań, także w świetle zacytowanych wypowiedzi osób z ZA, nie ma wątpliwości, że wykazują one deficyty w teorii umysłu, czym „narażają się” na brak akceptacji społecznej oraz na częste fiasko w zaspokojeniu swoich potrzeb. By podnieść swoje szanse posiadania przyjaciela, małżonka, dobrego pracodawcy, mozolnie trenują rozumienie powszechnych skryptów, uczą się stosowania komunikacyjnych figur retorycznych, nawiązywania kontaktu wzrokowego i wielu innych zachowań, typowych dla osób $z$ dobrze rozwiniętą teorią umysłu. Uczą się także jak kłamać. Całożyciowo uczą się zachowania, które będzie odpowiedzią na oczekiwania neurotypowej większości. 
A co w tej sprawie czyni owa większość, mając w pełnej dyspozycji empatię? Na ile osobista wiedza osoby z ZA jest dla większości zasobem do wymiany i współpracy? Pytania te wyznaczają kierunki kolejnych badań.

W dzisiejszym świecie społecznym rozumie się i szanuje potrzeby osób niepełnosprawnych ruchowo. Rozumie się tych, którzy poruszają się na wózku, podziwia tych, którzy zdobywają odległe zakątki poruszając się z pomocą protez. Likwiduje się architektoniczne bariery, montuje liczne usprawnienia, ogólnie wykazuje się troskę i empatię, ponieważ posiada się dobrze rozwiniętą teorię umysłu. Używając metafory fizycznej niepełnosprawności można stwierdzić, że osoba z ZA urodziła się bez pary sprawnie funkcjonujących nóg, ale codzienne podejmuje wysiłek chodzenia. W jaki sposób społeczeństwo pomaga jej pokonać bariery?

Zamiast odpowiedzi, na zakończenie przytoczono fragment wypowiedzi dorosłej kobiety z ZA, który być może stanie się podłożem refleksji rodziców, pedagogów i nauczycieli oraz wszystkich czytelników tego artykułu.

(...) Nie miałam również oparcia w nauczycielach poza polonistką, która dla każdego była miła i widziała mój potencjał pisarski oraz nauczycielem historii, który też był bardzo ciepłą osobą. Ale z nikim nie dzieliłam się sobą. Nie chciałam być dla nikogo problemem. Nauczyciele widzieli, że miałam problem z klasą, a właściwie - że to klasa miała ze mną problem, bo byłam „dziwadłem”, „nie z tej ziemi", dlatego często posyłali mnie do pedagoga, który zapewniał, że mi pomoże, ale po kątach podśmiechując ze mnie i wyjawiając wszystko osobom trzecim, przez co niektórzy nauczyciele zaczęli na mnie krzywo patrzeć, a w szczególności dyrektor, który nie cierpiał mojej rodziny (...) moi rodzice byli jedynymi, którzy bronili uczniów przed niesprawiedliwością ze strony grona pedagogicznego (Fragment wywiadu autorki z Olgą z ZA, lat 24).

\section{BIBLIOGRAFIA}

Asperger, H. (1944). Die autistischen Psychopathen im Kindesalter. Archiv für Psychiatrie und Nervenkrankheiten, 117, 76-136. Pozykano z: https://doi.org/10.1007/BFo1837709

Astington, J.W. i Jenkins, J.M. (1999). A Longitudinal Study of the Relation Between Language and Theory-of-Mind Development. Developmental Psychology, 35(5), 1311-1320. Pozyskano z: https://psycnet.apa.org/doi/10.1037/oo12-1649.35.5.1311

Baron-Cohen, S. (1995). Mindblindness. An Essay on Autism and Theory of Mind. Cambridge: MIT Press.

Begeer, S., Rieffe, C., Terwogt, M.M. i Stockmann, L. (2003). Theory of Mind-Based Action in Children from the Autism Spectrum. Journal of Autism and Developmental Disorders, 33(5), 479-487. Pozyskano z: https://doi.org/10.1023/A:1025875311062

Bellini, S. i Peters, J.K. (2008). Social Skills Training for Youth with Autism Spectrum Disorders. Child and Adolescent Psychiatric Clinics of North America, 17(4), 857-873. Pozyskano z: https://doi.org/10.1016/j.chc.2008.06.008

Brune, M. i Brune-Cohrs, U. (2006). Theory of Mind-Evolution, Ontogeny, Brain Mechanisms and Psychopathology. Neuroscience and Biobehavioral Reviews, 30, 437-455. Pozyskano z: https://doi.org/10.1016/j.neubiorev.2005.08.001 
Carlson, S.M., Koenig, M.A. i Harms, M.B. (2013). Theory of Mind. WIREs Cognitive Science, 4, 391-402. Pozyskano z: https://doi.org/10.1002/wcs.1232

Carlson, S.M., Moses, L.J. i Claxton, L.J. (2004). Individual Differences in Executive Functioning and Theory of Mind: An Investigation of Inhibitory Control and Planning Ability. Journal Experimental Child Psychology, 87(4), 299-319. Pozyskano z: https://doi. org/10.1016/j.jecp.2004.01.002

Dawson, G., Webb, S., Carter, L., Panagiotides, H. i McPartland, J. (2004). Young children with autism show antypical brain responses to fearful versus neutral facial expressions. Developmental Science, 7, 340-359. Pozyskano z: https://doi.org/10.1111/j.1467-7687.2004.00352.x

Decety, J. i Lamm, C. (2007). The Role of the Right Temporoparietal Junction in Social Interaction: How Low-Level Computational Processes Contribute to Meta-Cognition. Neuroscientist, 13, 580-593. Pozyskano z: https://doi.org/10.1177\%2F1073858407304654

Frith, U. (red.), (1991). Autism and Asperger Syndrome. Cambridge: Cambridge University Press.

Frith, U. (2001). Mind Blindness and the Brain in Autism. Neuron, 32, 969-979. Pozyskano z: https://doi.org/10.1016/So896-6273(01)00552-9

Frith, U. (2004). Autyzm. Wyjaśnienie tajemnicy. Gdańsk: Gdańskie Wydawnictwo Psychologiczne

Frith, U. i Frith, C.D. (2003). Development and Neurophysiology of Mentalizing. Philosophical Transactions of Royal Society of London (Series B: Biogical Sciences), 358(1431), 459-473. Pozyskano z: https://doi.org/10.1098/rstb.2002.1218

Frith, U. i Happé, F. (1994). Autism: Beyond “Theory of Mind”. Cognition, 50(1-3), 115-132. Pozyskano z: https://doi.org/10.1016/0010-0277(94)90024-8

Gallagher, H.L. i Frith, Ch.D. (2003). Functional Imaging of 'Theory of Mind'. Trends in Cognitive Sciences, 7(2), 77-83. Pozyskano z: https://doi.org/10.1016/S1364-6613(02)0oo25-6

Grice, S.J., Halit, H., Farroni, T., Baron-Cohen, S., Bolton, P. i Johnson, M.H. (2005). Neural Correlates of Eye-Gaze Detection in Young Children with Autism. Cortex, 41(3), 342-353. Pozyskano z: https://doi.org/10.1016/Soo10-9452(08)70271-5

Jakobson, L.S., Pearson, P.M., Kozub, Z., Hare, C. i Rigby, S.N. (2018). Links Between Traits Associated with the Broad Autism Phenotype and Empathy and Young Adults' Ability to Decode Speaker Intentionality. Research in Autism Spectrum Disorders, 50, 11-21. Pozyskano z: https://doi.org/10.1016/j.rasd.2018.03.001

Karpińska, D. (2011). Deficyt teorii umysłu w autyzmie. Symptomy i uwarunkowania. W: I. Kojder (red.), Neurokognitywistyka w patologii izdrowiu 2009-2011. Sympozja I. Szczecin: Pomorski Uniwersytet Medyczny.

Kerr-Gaffney, J., Harrison, A. i Tchanturia, K. (2020). Autism Spectrum Disorder Traits are Associated with Empathic Abilities in Adults with Anorexia Nervosa. Journal of Affective Disorders, 266(1), 273-281. Pozyskano z: 10.1016/j.jad.2020.01.169

Koning, C., Magill-Evans, J., Volden, J. i Dick, B. (2013). Efficacy of Cognitive Behavior Therapy-Based Social Skills Intervention for School-Aged Boys with Autism Spectrum Disorders. Research in Autism Spectrum Disorders, 7(10), 1282-129o. Pozyskano z: https://doi. org/10.1016/j.rasd.2011.07.011

Leslie, A.M. (1987). Pretense and Representation in Infancy: The Origins of 'Theory of Mind'. Psychological Review, 94(4), 412-426. Pozyskano z: https://oi.org/10.1037/0033295X.94.4.412

Leslie, A.M. (1994). Pretending and Believing: Issues in the Theory of Mind ToMM. Cognition, 5o(1-3), 211-238. Pozyskano z: https://doi.org/10.1016/0010-0277(94)90029-9

Leslie, A.M. i Thaiss, L. (1992). Domain Specificity in Conceptual Development: Neuropsychological Evidence from Autism. Cognition, 43(3), 225-251. Pozyskano z: https://doi. org/10.1016/0010-0277(92)90013-8 
Moody, Ch.T. i Laugeson, E.A. (2020). Social Skills Training in Autism Spectrum Disorder Across the Lifespan. Child and Adolescent Psychiatric Clinics of North America, 29(2), 359-371. Pozyskano z: https://doi.org/10.1016/j.chc.2019.11.001

Pears, K.C. i Moses, L.J. (2003). Demographics, Parenting, and Theory of Mind in Preschool Children. Social Development, 12(1), 1-20. Pozyskano z: https://doi.org/10.1111/14679507.00219

Pelphrey, K.A., Morris, J.P. i McCarthy, G. (2005). Neural Basis of Eye Gaze Processing Deficits in Autism. Brain, 128(5), 1038-1048. Pozyskano z: https://doi.org/10.1093/brain/awh404

Pepper, K.L., Demetriou, E.A., Park, S.H., Boulton, K.A., Hickie, I.B., Thomas, E.E. i Guastella, A.J. (2019). Self-Reported Empathy in Adults with Autism, Early Psychosis, and Social Anxiety Disorder. Psychiatry Research, 281, 112604. Pozyskano z: https://doi.org/10.1016/ j.psychres.2019.112604

Pluta, A. (2012). Mechanizmy poznawcze teorii umysłu. Roczniki Psychologiczne, 15(1), 7-30. Pozyskano z: http://www.kul.pl/files/1024/Roczniki_Psychologiczne/2012/1/RPsych_2012 _vol15_no1_007-030_PLUTA.pdf

Ratcliffe, B., Wong, M., Dossetor, D. i Hayes, S. (2014). Teaching Social-Emotional Skills to School-Aged Children with Autism Spectrum Disorder: A Treatment Versus Control Trial in 41 Mainstream Schools. Research in Autism Spectrum Disorders, 8(12), 1722-1733. Pozyskano z: https://doi.org/10.1016/j.rasd.2014.09.010

Rynkiewicz, A., Janas-Kozik, M. i Słopień, A. (2019). Dziewczęta i kobiety z autyzmem. Psychiatria Polska, 53(4), 737-752. Pozyskano z: https://doi.org/10.12740/PP/OnlineFirst/95098

Saxe, R., Wexler, A. (2005). Making Sense of Another Mind: The Role of the Right Temporoparietal Junction. Neuropsychologia, 43(10), 1391-1399. Pozyskano z: https://doi.org/10.1016/ j.neuropsychologia.2005.02.013

Schank, R.C. (1982). Dynamic Memory. Cambridge: Cambridge University Press.

Schank, R.C., Fano, A. (1995). Memory and expectations in learning, language, and visual understanding. Artificial Intelligence Review, 9(4-5), 261-271. Pozyskano z: https://psycnet. apa.org/doi/10.1007/BFoo849039

Senju, A. i Johnson, M.H. (2009). Atypical Eye Contact in Autism: Models, Mechanisms and Development. Neuroscience \& Biobehavioral Reviews, 33(8), 1204-1214. Pozyskano z: https://doi.org/10.1016/j.neubiorev.2009.06.001

Senju, A., Tojo, Y., Yaguchi, K. i Hasegawa, T. (2005). Deviant Gaze Processing in Children with Autism: an ERP Study. Neuropsychologia, 43(9), 1297-1306. Pozyskano z: https://doi. org/10.1016/j.neuropsychologia.2004.12.002

Sodian, B. i Frith, U. (1992). Deception and Sabotage in Autistic, Retarded and Normal Children. Journal of Child Psychology and Psychiatry, and Allied Disciplines, 33(3), 591-605. Pozyskano z: https://doi.org/10.1111/j.1469-7610.1992.tboo893.X

Stone, V. i Gerrans, P. (2006). Does the Normal Brain Have a Theory of Mind? Trends in Cognitive Sciences, 10(1), 3-4. Pozyskano z: https://doi.org/10.1016/j.tics.2005.11.010

Szamburska-Lewandowska, K., Konowałek, Ł. i Bryńska, A. (2020). Deficyty Teorii Umysłu w wybranych zaburzeniach psychicznych wieku rozwojowego. Psychiatria Polska, 195, 1-13. Pozyskano z: https://doi.org/10.12740/PP/OnlineFirst/112708

Świtała, I.M. (2019). Wychowanie do wartości w zmieniającym się świecie. Studia Edukacyjne, $52,159-172$.

WHO (2008). Międzynarodowa Statystyczna Klasyfikacja Chorób i Problemów Zdrowotnych. Rewizja dziesiąta. T. I. WHO, Genewa.

Winczura, B. (2014). Deficiencies of Eye Contact and Faceto-Face Interactions in Social Relations Among Children with Autism. Pedagogika, 116(4), 226-239. Pozyskano z: http:// dx.doi.org/10.15823/p.2015.060

Woodbury-Smith, M.R. i Volkmar, F.R. (2009). Asperger syndrome. European Child \& Adolescent Psychiatry, 18(1), 2-11. Pozyskano z: https://doi.org/10.1007/so0787-008-0701-o 


\section{SUMMARY}

\section{Theory of Mind, Social Expectations, and the Situation of People with Autistic Spectrum Disorders, including People with Asperger Syndrome}

The author attempted to analyse the state of research on the Theory of Mind and its deficit in people with Autistic Spectrum Disorders (ASD), especially those with Asperger Syndrome (AS). This analysis also searched for connections between the Theory of Mind and expectations which set the rules of social interdependence. In the aspect of the analysed research, it can be concluded that the Theory of Mind is connected - through a common expectation of empathy - with the need and the rules of acceptance and respect. The biologically conditioned deficit of the Theory of Mind of people with ASD causes a high risk of rejecting these people because they do not meet social expectations.

KEYWORDS: Theory of Mind, Autistic Spectrum Disorder, Asperger Syndrome, social expectations 